Article

\title{
Chemical Composition and Antimicrobial and Antioxidant Activities of Essential Oil of Sunflower (Helianthus annuus L.) Receptacle
}

\author{
Xin-Sheng Liu ${ }^{1,+}{ }^{+}$Bo Gao ${ }^{1,2,+}$, Xin-Lu Li ${ }^{1}$, Wan-Nan $\mathrm{Li}^{1}{ }^{1}$, Zi-An Qiao ${ }^{1}$ and Lu Han ${ }^{1,2,3, * \mathbb{C}}$ \\ 1 School of Life Science, Jilin University, Changchun 130012, China; liuxs18@mails.jlu.edu.cn (X.-S.L.); \\ gaobo@jlu.edu.cn (B.G.); xinlu19@mails.jlu.edu.cn (X.-L.L.); liwannan@jlu.edu.cn (W.-N.L.); \\ qiaoza18@mails.jlu.edu.cn (Z.-A.Q.) \\ 2 Key Laboratory for Molecular Enzymology and Engineering, Jilin University, Ministry of Education, \\ Changchun 130012, China \\ 3 Key Laboratory for Evolution of Past Life and Environment in Northeast Asia, Jilin University, \\ Ministry of Education, Changchun 130012, China \\ * Correspondence: luhan@jlu.edu.cn; Tel.: +86-431-8515-5345; Fax: +86-431-8515-5127 \\ + These authors contributed equally to this work.
}

Received: 3 October 2020; Accepted: 5 November 2020; Published: 11 November 2020

\begin{abstract}
Sunflower (Helianthus annuus L.) contains active ingredients, such as flavonoids, alkaloids and tannins. Nevertheless, few studies have focused on essential oil from the receptacle of sunflower (SEO). In this work, we investigated the chemical composition and antimicrobial and antioxidant activities of SEO. The yield of SEO was about $0.42 \%(v / w)$ by hydrodistillation. A total of 68 volatile components of SEO were putatively identified by gas chromatography-mass spectrometry (GC-MS). The main constituents of SEO were $\alpha$-pinene $(26.00 \%)$, verbenone $(7.40 \%)$, terpinolene $(1.69 \%)$ and $\alpha$-terpineol (1.27\%). The minimum inhibitory concentration (MIC) of SEO against P. aeruginosa and S. aureus was $0.2 \mathrm{mg} / \mathrm{mL}$. The MIC of SEO against S. cerevisiae was $3.2 \mathrm{mg} / \mathrm{mL}$. The MIC of SEO against E. coli and Candida albicans was $6.4 \mathrm{mg} / \mathrm{mL}$. The results showed that SEO had high antibacterial and antifungal activities. Three different analytical assays (DPPH, ABTS and iron ion reducing ability) were used to determine the antioxidant activities. The results showed that SEO had antioxidant activities. To summarize, the results in this study demonstrate the possibility for the development and application of SEO in potential natural preservatives and medicines due to its excellent antimicrobial and antioxidant activities.
\end{abstract}

Keywords: sunflower (Helianthus annuus L.); essential oil; chemical composition; antimicrobial activity; antioxidant activity

\section{Introduction}

Sunflower (Helianthus annuus L.) is an annual dicotyledonous plant that belongs to the family Asteraceae and is widely distributed in North America, Eastern Europe and Northern China [1]. Sunflower roots, stems, leaves and seeds contained phenols, flavonoids and alkaloids [2]. In previous studies, sunflower florets were found to contain dietary fiber and phenolic acid [3]. Sunflower petals were found to have triterpene glycosides, which had anti-inflammatory activity [4]. The ethanolic extract of sunflower seeds has a potential antidiabetic property in type 2 diabetes mellitus [5]. The aqueous extract of sunflower seeds was found to have considerable potential in reducing asthma symptoms [6] and high antioxidant activity [7]. The sunflower receptacle has always been discarded because of a lack of studies focusing on its commercial application. 
In previous studies, essential oil was obtained from roots, stems and leaves of plants by hydrodistillation [8]. Significant differences have been found in the essential oil contents of different sunflower parts. Previous research showed that $\alpha$-pinene was higher in flowers (72.6\%) than in leaves $(28.6 \%)$ [9]. In capitula and pollen, $\alpha$-pinene was found at $20.0 \%$, in addition to monoterpene and sesquiterpene hydrocarbons [10]. The previous study proved that sunflower head reduced the level of uric acid and thus may be used as a Chinese traditional drug for treating gout [11]. However, the chemical composition and biological activities of sunflower receptacle essential oil (SEO) have not been studied before.

To our knowledge, there are no reports on the antimicrobial and antioxidant activities of SEO. This study aimed to evaluate the chemical composition and antimicrobial and antioxidant activities of SEO to determine the potential application of the sunflower receptacle in food and medical fields. The development and utilization of the sunflower receptacle can benefit from scientific guidance provided through the study of the chemical composition and biological activity of SEO.

\section{Results and Discussion}

\subsection{Yield and Chemical Composition of SEO}

SEO was extracted by hydrodistillation for $8 \mathrm{~h}$. The average yield of SEO was about $0.42 \%(v / w)$ in this study. In the previous study, the yield of essential oil from dried sunflower head was $0.20 \%$ $(w / w)$ by steam distillation at $100{ }^{\circ} \mathrm{C}$ for $6 \mathrm{~h}$ [12]. The essential oil yields from the Carlos and Florom 350 hybrid sunflower heads were found to be $0.12 \%$ and $0.13 \%$ by hydrodistillation for $2 \mathrm{~h}$, respectively [9].

Pentadecane was used as an internal standard, and $\alpha$-pinene, verbenone, terpinolene and $\alpha$-terpineol were used as external standards. Sixty eight chemical components of SEO were putatively identified by GC-MS analysis, accounting for $92.07 \%$ of the total content of essential oil, as shown in Table 1, Figure A1 and Table A1. The major chemical component was $\alpha$-pinene $(26.00 \%)$. The other main components were verbenone $(7.40 \%)$, calarene (5.27\%), kaur-16-ene (3.51\%) and terpinolene (1.69\%). Among the 68 chemical compounds, most of them were monoterpenoids (54.65\%), mainly including $\alpha$-pinene, $\alpha$-terpineol, verbenone and terpinolene. Sesquiterpenoids content was $22.73 \%$; content of others was $14.69 \%$.

The main chemical components were $\alpha$-pinene and verbenone, which were all found in sunflower receptacle, capitula and pollen, as shown in Table 2. Among the main chemical components of essential oil, $\alpha$-pinene was present in the highest amount. Some chemical components of essential oil, such as terpinolene, $\alpha$-terpineol, pinocarvone and cis-verbenol, were found in both sunflower receptacle and capitula. However, the most of chemical components of essential oil from different sunflower parts (receptacle, capitula and pollen) were different. For example, kaur-16-ene, 16-kaur-16-ol and kauran-16-ol were unique chemical components of the sunflower receptacle. A previous study showed that kaur-16-ene strongly inhibited cancer cells [13], so SEO may have the potential to inhibit cancer cells. 
Table 1. Chemical composition of SEO.

\begin{tabular}{|c|c|c|c|c|c|c|c|c|}
\hline NO. & Compound & Molecular Formula & $\mathrm{RT}^{\mathrm{a}}$ & $R^{b}$ & $\mathrm{MF}^{\mathrm{c}}$ & RMF $^{d}$ & Content (\%) & Identification \\
\hline 1 & $\alpha$-Pinene & $\mathrm{C}_{10} \mathrm{H}_{16}$ & 3.70 & 930 & 953 & 954 & 26.00 & $1,2,3$ \\
\hline 2 & Camphene & $\mathrm{C}_{10} \mathrm{H}_{16}$ & 3.87 & 943 & 906 & 911 & 0.21 & 1,2 \\
\hline 3 & 2,4-Thujadiene & $\mathrm{C}_{10} \mathrm{H}_{14}$ & 3.93 & 957 & 844 & 858 & 0.76 & 1,2 \\
\hline 4 & $\beta$-Terpinene & $\mathrm{C}_{10} \mathrm{H}_{16}$ & 4.26 & 964 & 876 & 918 & 0.15 & 1,2 \\
\hline 5 & L- $\beta$-Pinene & $\mathrm{C}_{10} \mathrm{H}_{16}$ & 4.31 & 969 & 926 & 935 & 0.38 & 1,2 \\
\hline 6 & Epoxycyclooctane & $\mathrm{C}_{8} \mathrm{H}_{14} \mathrm{O}$ & 4.39 & 971 & 896 & 912 & 0.22 & 1,2 \\
\hline 7 & 2,3-Dehydro-1,8-cineole & $\mathrm{C}_{10} \mathrm{H}_{16} \mathrm{O}$ & 4.50 & 1041 & 791 & 835 & 0.33 & 1,2 \\
\hline 8 & 1,3,8-p-Menthatriene & $\mathrm{C}_{10} \mathrm{H}_{14}$ & 4.56 & 1042 & 872 & 913 & 0.25 & 1,2 \\
\hline 9 & $E, E-2,6$-Dimethyl-1,3,5,7-octatetraene & $\mathrm{C}_{10} \mathrm{H}_{14}$ & 4.79 & 1049 & 902 & 915 & 0.27 & 1,2 \\
\hline 10 & 4-Isopropenyltoluene & $\mathrm{C}_{10} \mathrm{H}_{12}$ & 4.87 & 1073 & 849 & 895 & 0.07 & 1,2 \\
\hline 11 & o-Cymene & $\mathrm{C}_{10} \mathrm{H}_{14}$ & 5.10 & 1079 & 929 & 939 & 0.62 & 1,2 \\
\hline 12 & Isosylvestrene & $\mathrm{C}_{10} \mathrm{H}_{16}$ & 5.27 & 1083 & 879 & 923 & 0.11 & 1,2 \\
\hline 13 & $\gamma$-Terpinen & $\mathrm{C}_{10} \mathrm{H}_{16}$ & 5.83 & 1101 & 908 & 918 & 0.18 & 1,2 \\
\hline 14 & trans- $p$-Mentha-2,8-dienol & $\mathrm{C}_{10} \mathrm{H}_{16} \mathrm{O}$ & 5.99 & 1111 & 746 & 747 & 1.30 & 1,2 \\
\hline 15 & Berbenol & $\mathrm{C}_{10} \mathrm{H}_{16} \mathrm{O}$ & 6.16 & 1117 & 824 & 830 & 0.13 & 1,2 \\
\hline 16 & Campholenal & $\mathrm{C}_{10} \mathrm{H}_{16} \mathrm{O}$ & 6.24 & 1119 & 854 & 875 & 0.10 & 1,2 \\
\hline 17 & 4-Isopropenyltoluene & $\mathrm{C}_{10} \mathrm{H}_{12}$ & 6.31 & 1123 & 919 & 940 & 0.33 & 1,2 \\
\hline 18 & Terpinolene & $\mathrm{C}_{10} \mathrm{H}_{16}$ & 6.40 & 1124 & 901 & 925 & 1.69 & $1,2,3$ \\
\hline 19 & Benzyl ethyl carbinol & $\mathrm{C}_{10} \mathrm{H}_{14} \mathrm{O}$ & 7.05 & 1131 & 761 & 799 & 0.35 & 1,2 \\
\hline 20 & L-Pinocarveol & $\mathrm{C}_{10} \mathrm{H}_{16} \mathrm{O}$ & 7.24 & 1143 & 920 & 928 & 0.17 & 1,2 \\
\hline 21 & cis-Verbenol & $\mathrm{C}_{10} \mathrm{H}_{16} \mathrm{O}$ & 7.32 & 1146 & 862 & 899 & 0.82 & 1,2 \\
\hline 22 & d-Verbenol & $\mathrm{C}_{10} \mathrm{H}_{16} \mathrm{O}$ & 7.41 & 1149 & 917 & 919 & 4.11 & 1,2 \\
\hline 23 & Pinocarvone & $\mathrm{C}_{10} \mathrm{H}_{14} \mathrm{O}$ & 7.54 & 1157 & 873 & 891 & 1.14 & 1,2 \\
\hline 24 & L-Terpinen-4-ol & $\mathrm{C}_{10} \mathrm{H}_{18} \mathrm{O}$ & 8.00 & 1158 & 909 & 920 & 0.56 & 1,2 \\
\hline 25 & p-Cymen-8-ol & $\mathrm{C}_{10} \mathrm{H}_{14} \mathrm{O}$ & 8.07 & 1160 & 906 & 920 & 0.61 & 1,2 \\
\hline 26 & Myrtenal & $\mathrm{C}_{10} \mathrm{H}_{14} \mathrm{O}$ & 8.13 & 1169 & 927 & 933 & 0.07 & 1,2 \\
\hline 27 & $\alpha$-Terpineol & $\mathrm{C}_{10} \mathrm{H}_{18} \mathrm{O}$ & 8.19 & 1172 & 821 & 839 & 1.27 & $1,2,3$ \\
\hline 28 & Verbenone & $\mathrm{C}_{10} \mathrm{H}_{14} \mathrm{O}$ & 8.34 & 1198 & 908 & 917 & 7.40 & $1,2,3$ \\
\hline 29 & cis-Carveol & $\mathrm{C}_{10} \mathrm{H}_{16} \mathrm{O}$ & 8.76 & 1207 & 942 & 944 & 2.20 & 1,2 \\
\hline 30 & L-Carveol & $\mathrm{C}_{10} \mathrm{H}_{16} \mathrm{O}$ & 8.95 & 1213 & 704 & 719 & 0.25 & 1,2 \\
\hline 31 & Carvol & $\mathrm{C}_{10} \mathrm{H}_{14} \mathrm{O}$ & 9.02 & 1217 & 857 & 894 & 0.25 & 1,2 \\
\hline 32 & Hotrienol & $\mathrm{C}_{10} \mathrm{H}_{16} \mathrm{O}$ & 9.10 & 1218 & 657 & 747 & 0.17 & 1,2 \\
\hline 33 & 3,5-Diethylphenol & $\mathrm{C}_{10} \mathrm{H}_{14} \mathrm{O}$ & 9.17 & 1219 & 762 & 799 & 0.16 & 1,2 \\
\hline 34 & trans-2-Caren-4-ol & $\mathrm{C}_{10} \mathrm{H}_{16} \mathrm{O}$ & 9.38 & 1224 & 734 & 750 & 0.19 & 1,2 \\
\hline 35 & Bornyl acetate & $\mathrm{C}_{12} \mathrm{H}_{20} \mathrm{O}_{2}$ & 9.95 & 1259 & 887 & 892 & 0.72 & 1,2 \\
\hline 36 & (-)-trans-Pinocarvyl acetate & $\mathrm{C}_{12} \mathrm{H}_{18} \mathrm{O}_{2}$ & 10.16 & 1264 & 742 & 754 & 0.15 & 1,2 \\
\hline 37 & 4-Vinylguaiacol & $\mathrm{C}_{9} \mathrm{H}_{10} \mathrm{O}_{2}$ & 10.25 & 1271 & 818 & 845 & 0.25 & 1,2 \\
\hline
\end{tabular}


Table 1. Cont.

\begin{tabular}{|c|c|c|c|c|c|c|c|c|}
\hline NO. & Compound & Molecular Formula & $\mathrm{RT}^{\mathrm{a}}$ & $\mathbf{R I}^{\mathbf{b}}$ & $\mathrm{MF}^{\mathrm{c}}$ & RMF $^{d}$ & Content (\%) & Identification $^{\mathrm{e}}$ \\
\hline 38 & 1,4-p-Menthadien-7-ol & $\mathrm{C}_{10} \mathrm{H}_{16} \mathrm{O}$ & 10.65 & 1291 & 739 & 774 & 0.31 & 1,2 \\
\hline 39 & Aromadendrene, dehydro- & $\mathrm{C}_{15} \mathrm{H}_{22}$ & 12.42 & 1407 & 747 & 778 & 0.25 & 1,2 \\
\hline 40 & Calarene & $\mathrm{C}_{15} \mathrm{H}_{24}$ & 12.55 & 1412 & 903 & 930 & 5.27 & 1,2 \\
\hline 41 & 4,5,9,10-dehydro-Isolongifolene & $\mathrm{C}_{15} \mathrm{H}_{20}$ & 12.91 & 1424 & 752 & 764 & 0.25 & 1,2 \\
\hline 42 & 2-Tridecanone & $\mathrm{C}_{13} \mathrm{H}_{26} \mathrm{O}$ & 13.39 & 1439 & 885 & 896 & 0.33 & 1,2 \\
\hline 43 & Bisabolene & $\mathrm{C}_{15} \mathrm{H}_{24}$ & 13.69 & 1450 & 896 & 912 & 0.52 & 1,2 \\
\hline 44 & Cadina-3,9-diene & $\mathrm{C}_{15} \mathrm{H}_{24}$ & 13.86 & 1456 & 835 & 851 & 0.30 & 1,2 \\
\hline 45 & Juniper camphor & $\mathrm{C}_{15} \mathrm{H}_{26} \mathrm{O}$ & 14.20 & 1467 & 790 & 801 & 0.30 & 1,2 \\
\hline 46 & (-)-Spathulenol & $\mathrm{C}_{15} \mathrm{H}_{24} \mathrm{O}$ & 14.52 & 1478 & 842 & 849 & 0.51 & 1,2 \\
\hline 47 & Caryophyllene oxide & $\mathrm{C}_{15} \mathrm{H}_{24} \mathrm{O}$ & 14.59 & 1480 & 661 & 689 & 0.18 & 1,2 \\
\hline 48 & Isoaromadendrene epoxide & $\mathrm{C}_{15} \mathrm{H}_{24} \mathrm{O}$ & 14.90 & 1490 & 775 & 791 & 0.70 & 1,2 \\
\hline 49 & cis-Lanceol & $\mathrm{C}_{15} \mathrm{H}_{24} \mathrm{O}$ & 15.00 & 1494 & 749 & 805 & 0.43 & 1,2 \\
\hline 50 & 3,3,5,6,7-Pentamethyl-1-indanone & $\mathrm{C}_{14} \mathrm{H}_{18} \mathrm{O}$ & 15.35 & 1505 & 790 & 791 & 2.96 & 1,2 \\
\hline 51 & Trans-Longipinocarveol & $\mathrm{C}_{15} \mathrm{H}_{24} \mathrm{O}$ & 16.09 & 1530 & 723 & 758 & 0.52 & 1,2 \\
\hline 52 & Dehydro-cyclolongifolene oxide & $\mathrm{C}_{15} \mathrm{H}_{22} \mathrm{O}$ & 16.87 & 1556 & 740 & 752 & 4.81 & 1,2 \\
\hline 53 & Tetradecanoic acid & $\mathrm{C}_{14} \mathrm{H}_{28} \mathrm{O}_{2}$ & 17.20 & 1567 & 701 & 778 & 0.15 & 1,2 \\
\hline 54 & 9-Hexadecenoic acid & $\mathrm{C}_{16} \mathrm{H}_{30} \mathrm{O}_{2}$ & 19.40 & 1701 & 661 & 669 & 0.22 & 1,2 \\
\hline 55 & Androst-2,16-diene & $\mathrm{C}_{19} \mathrm{H}_{28}$ & 19.62 & 1709 & 738 & 743 & 0.19 & 1,2 \\
\hline 56 & Phellopterin & $\mathrm{C}_{17} \mathrm{H}_{16} \mathrm{O}_{5}$ & 19.77 & 1773 & 766 & 786 & 2.17 & 1,2 \\
\hline 57 & Hexadecanoic acid & $\mathrm{C}_{16} \mathrm{H}_{32} \mathrm{O}_{2}$ & 19.84 & 1775 & 878 & 895 & 2.26 & 1,2 \\
\hline 58 & Manoyl oxide & $\mathrm{C}_{20} \mathrm{H}_{34} \mathrm{O}$ & 20.12 & 1945 & 868 & 889 & 0.23 & 1,2 \\
\hline 59 & Androstane-3,11-diol & $\mathrm{C}_{19} \mathrm{H}_{32} \mathrm{O}_{2}$ & 20.81 & 1985 & 711 & 736 & 0.32 & 1,2 \\
\hline 60 & Methyl isopimarate & $\mathrm{C}_{21} \mathrm{H}_{32} \mathrm{O}_{2}$ & 21.35 & 1998 & 742 & 802 & 0.37 & 1,2 \\
\hline 61 & Linoleic acid & $\mathrm{C}_{18} \mathrm{H}_{32} \mathrm{O}_{2}$ & 21.57 & 2008 & 793 & 847 & 1.00 & 1,2 \\
\hline 62 & trans-Oleic acid & $\mathrm{C}_{18} \mathrm{H}_{34} \mathrm{O}_{2}$ & 21.65 & 2012 & 629 & 691 & 0.27 & 1,2 \\
\hline 63 & Kaur-16-ene & $\mathrm{C}_{20} \mathrm{H}_{32}$ & 22.23 & 2037 & 852 & 872 & 3.51 & 1,2 \\
\hline 64 & 16-Kauran-16-ol & $\mathrm{C}_{20} \mathrm{H}_{34} \mathrm{O}$ & 22.30 & 2040 & 870 & 888 & 1.65 & 1,2 \\
\hline 75 & Kauran-16-ol & $\mathrm{C}_{20} \mathrm{H}_{34} \mathrm{O}$ & 22.43 & 2045 & 847 & 869 & 0.99 & 1,2 \\
\hline 66 & Cryptopinon & $\mathrm{C}_{20} \mathrm{H}_{30} \mathrm{O}$ & 22.59 & 2052 & 769 & 798 & 0.29 & 1,2 \\
\hline 67 & Pimaric acid & $\mathrm{C}_{20} \mathrm{H}_{30} \mathrm{O}_{2}$ & 23.71 & 2101 & 739 & 741 & 3.09 & 1,2 \\
\hline \multirow[t]{6}{*}{68} & Abietic acid & $\mathrm{C}_{20} \mathrm{H}_{30} \mathrm{O}_{2}$ & 24.26 & 2125 & 785 & 786 & 3.78 & 1,2 \\
\hline & Pentadecane $\mathrm{f}^{\mathrm{f}}$ & & & & & & & \\
\hline & Total compounds & & & & & & 92.07 & \\
\hline & Oxygenated monoterpenes & & & & & & 54.65 & \\
\hline & Sesquiterpenoids & & & & & & 22.73 & \\
\hline & Others & & & & & & 14.69 & \\
\hline
\end{tabular}

a Peak time. ${ }^{\mathrm{b}}$ Retention indices relative to C9-C30 n-alkanes on the HP-INNOWax column. ${ }^{\mathrm{c}}$ Forward match. ${ }^{\mathrm{d}}$ Reverse match. ${ }^{\mathrm{e}}$ Methods of identification: 1 , retention index; 2 , mass spectrum; 3 , co-injection with standard compound. ${ }^{\mathrm{f}}$ Internal standard. 
Table 2. Comparison of the main components of essential oil from different sunflower parts (receptacle, capitula and pollen).

\begin{tabular}{|c|c|c|c|c|c|c|}
\hline \multirow[b]{2}{*}{ Compound } & \multicolumn{2}{|c|}{ Receptacle } & \multicolumn{2}{|c|}{ Capitula $^{\text {a }}[9]$} & \multicolumn{2}{|c|}{ Pollen ${ }^{b}[10]$} \\
\hline & $\mathrm{RI}^{\mathrm{c}}$ & $\begin{array}{c}\text { Content } \\
(\%)\end{array}$ & RI & $\begin{array}{c}\text { Content } \\
(\%)\end{array}$ & RI & $\begin{array}{c}\text { Content } \\
(\%)\end{array}$ \\
\hline$\alpha$-Pinene & 930 & 26.00 & 940 & 74.50 & 941 & 20.57 \\
\hline Verbenone & 1198 & 7.40 & 1206 & 0.2 & 1205 & 1.52 \\
\hline Calarene & 1412 & 5.27 & - & - & - & - \\
\hline Dehydro-cyclolongifolene oxide & 1556 & 4.81 & - & - & - & - \\
\hline d-Verbenol & 1149 & 4.11 & - & - & - & - \\
\hline Abietic acid & 2125 & 3.78 & - & - & - & - \\
\hline Kaur-16-ene & 2037 & 3.51 & - & - & - & - \\
\hline Pimaric acid & 2101 & 3.09 & - & - & - & - \\
\hline 3,3,5,6,7-Pentamethyl-1-Indanone & 1505 & 2.96 & - & - & - & - \\
\hline Hexadecanoic acid & 1775 & 2.26 & - & - & - & - \\
\hline cis-Carveol & 1207 & 2.20 & - & - & - & - \\
\hline Phellopterin & 1773 & 2.17 & - & - & - & - \\
\hline Terpinolene & 1124 & 1.69 & 1089 & 0.2 & - & - \\
\hline 16-Kaur-16-ol & 2040 & 1.65 & - & - & - & - \\
\hline$\alpha$-Terpineol & 1172 & 1.27 & 1020 & 0.4 & - & - \\
\hline trans- $p$-Mentha-2,8-dienol & 1111 & 1.30 & 1126 & 0.05 & - & - \\
\hline Pinocarvone & 1157 & 1.14 & 1164 & 0.1 & - & - \\
\hline Linoleic acid & 2008 & 1.00 & - & - & - & - \\
\hline Kauran-16-ol & 2045 & 0.99 & - & - & - & - \\
\hline cis-Verbenol & 1146 & 0.82 & 1143 & 0.7 & - & - \\
\hline
\end{tabular}

${ }^{a}$ The essential oil of sunflower capitula was extracted by water distillation in a Clevenger-type apparatus, and the components were identified by GC-MS. ${ }^{b}$ The volatile components of sunflower pollen were identified by headspace solid-phase microextraction (HS-SPME)/GC-MS technique. ${ }^{c}$ Retention indices. -, not detected with the same compounds and retention indices.

\subsection{Antimicrobial Activities of SEO against Bacteria and Fungi}

We evaluated antimicrobial activities of SEO against bacteria (Escherichia coli, Pseudomonas aeruginosa and Staphylococcus aureus) and fungi (Saccharomyces cerevisiae and Candida albicans) by MIC and minimum bactericidal concentration (MBC). Tetracycline hydrochloride was used as positive control against bacteria, and miconazole nitrate was used as positive control against fungi.

\subsubsection{Antibacterial Activities}

Monomer mixtures contained $\alpha$-terpineol, $\alpha$-pinene, terpinolene and verbenone ( $\mathrm{m}: \mathrm{m}: \mathrm{m}: \mathrm{m}=1: 1: 1: 1)$. The antibacterial activities of SEO, monomer mixtures and monomers ( $\alpha$-pinene, verbenone, $\alpha$-terpineol and terpinolene) were evaluated against E. coli, P. aeruginosa and S. aureus (Tables 3 and A2). The results indicated that the MIC of SEO was $0.2 \mathrm{mg} / \mathrm{mL}$ against $P$. aeruginosa and $S$. aureus. The MIC of $\alpha$-pinene was $6.4 \mathrm{mg} / \mathrm{mL}$ against $P$. aeruginosa and $S$. aureus. The MBC of $\alpha$-terpineol against $P$. aeruginos $a$ and S. aureus was $6.4 \mathrm{mg} / \mathrm{mL}$. The MIC and MBC of $\alpha$-terpineol against $E$. coli were $6.4 \mathrm{mg} / \mathrm{mL}$. The MIC of monomer mixtures was $1.6 \mathrm{mg} / \mathrm{mL}$ against $P$. aeruginosa and $S$. aureus. A previous study showed that $\alpha$-terpineol had antibacterial activity with a mechanism of changing the morphology of E. coli [14].

The MIC and MBC of SEO were lower than those of the monomer mixture. The MIC and MBC of SEO were lower than those of each monomer. The results showed that the antibacterial effect of SEO was better than that of the monomer mixture and each monomer. The results also implied that the other monomers of SEO may play an important role in the antibacterial effect.

Essential oils from other plants, such as essential oil of Mentha citrata Ehrh., Artemisia annua L. and Citrus medica L., were found to have antibacterial activities. Essential oil of Mentha citrata Ehrh. had significant antibacterial activity at $0.5 \mathrm{mg} / \mathrm{mL}$ against $S$. aureus [15]. The MIC of the essential oil from Artemisia annua L. against S. aureus was $10 \mathrm{mg} / \mathrm{mL}$ [16]. The essential oil from fruits of Citrus medica $\mathrm{L}$. 
had the MIC of $1.56 \mathrm{mg} / \mathrm{mL}$ against S. aureus [17]. In this work, SEO was found to have antibacterial activity against $S$. aureus (MIC $=0.2 \mathrm{mg} / \mathrm{mL}$ ). The smaller MIC value indicates the better antibacterial activity of essential oil. The results showed that SEO had better antibacterial activities than essential oils of other plants, such as Mentha citrata Ehrh., Artemisia annua L. and Citrus medica L.

Table 3. Antibacterial activities of SEO and the main monomers.

\begin{tabular}{ccccccc}
\hline \multirow{2}{*}{ Sample } & \multicolumn{2}{c}{ E. coli } & \multicolumn{2}{c}{ P. aeruginosa } & \multicolumn{2}{c}{ S. aureus } \\
\cline { 2 - 7 } & $\begin{array}{c}\text { MIC } \\
(\mathbf{m g} / \mathbf{m L})\end{array}$ & $\begin{array}{c}\text { MBC } \\
(\mathbf{m g} / \mathbf{m L})\end{array}$ & $\begin{array}{c}\text { MIC } \\
(\mathbf{m g} / \mathbf{m L})\end{array}$ & $\begin{array}{c}\text { MBC } \\
(\mathbf{m g} / \mathbf{m L})\end{array}$ & $\begin{array}{c}\text { MIC } \\
(\mathbf{m g} / \mathbf{m L})\end{array}$ & $\begin{array}{c}\mathbf{M B C} \\
(\mathbf{m g} / \mathbf{m L})\end{array}$ \\
\hline SEO & 6.4 & 12.8 & 0.2 & 0.2 & 0.2 & 0.4 \\
$\alpha$-Pinene & 12.8 & $>12.8$ & 6.4 & 12.8 & 6.4 & 6.4 \\
$\alpha$-Terpineol & 6.4 & 6.4 & 3.2 & 6.4 & 6.4 & 6.4 \\
Terpinolene $_{\text {Verbenone }}$ & $>12.8$ & $>12.8$ & $>12.8$ & $>12.8$ & 6.4 & 6.4 \\
Mixture $^{\mathrm{a}}$ & 12.8 & $>12.8$ & $>12.8$ & $>12.8$ & 3.2 & 3.2 \\
Tetracycline $^{\mathrm{b}}$ & $\mathrm{ND}$ & 3.2 & 1.6 & 1.6 & 1.6 & 1.6 \\
\hline
\end{tabular}

$\mathrm{ND}$, not detected. a Monomer mixture containing $\alpha$-pinene, verbenone, terpinolene and $\alpha$-terpineol $(\mathrm{m}: \mathrm{m}: \mathrm{m}: \mathrm{m}=1: 1: 1: 1){ }^{\mathrm{b}}$ Tetracycline hydrochloride was used as positive control for inhibiting bacteria.

E. coli, S. aureus and P. aeruginosa are the main pathogens causing some diseases affecting human health, such as diarrhea, urinary tract infections, skin infections and respiratory diseases [18-20]. In this study, SEO was found to have significant antibacterial properties against both Gram-positive and Gram-negative bacteria.

\subsubsection{Antifungal Activities}

We evaluated the antifungal activities of SEO and monomers by using S. cerevisiae and Candida albicans. Tables 4 and A3 summarized MIC and MBC of SEO and monomers. The MIC of SEO results implied that SEO had the highest antifungal activities against $S$. cerevisiae at $3.2 \mathrm{mg} / \mathrm{mL}$. The antifungal activities of the major monomers of SEO, namely $\alpha$-pinene, $\alpha$-terpineol, verbenone and terpinolene, were tested separately. The results showed that $\alpha$-pinene had the highest antifungal activity against $S$. cerevisiae $(\mathrm{MIC}=0.8 \mathrm{mg} / \mathrm{mL}$ and $\mathrm{MBC}=1.6 \mathrm{mg} / \mathrm{mL})$ out of the SEO monomers. In addition, the $\alpha$-pinene content of SEO was $26.00 \%$. Previous studies also found that $\alpha$-pinene had a great antifungal effect [21]. The other three main monomers, namely verbenone, terpinolene and $\alpha$-terpineol, had strong antifungal activities, showing that $\alpha$-pinene, $\alpha$-terpineol, terpinolene and verbenone play primary roles in the antifungal activities of SEO against $S$. cerevisiae and Candida albicans.

Table 4. Antifungal activities of SEO and the main monomers.

\begin{tabular}{ccccc}
\hline \multirow{2}{*}{ Sample } & \multicolumn{2}{c}{ S. cerevisiae } & \multicolumn{2}{c}{ Candida albicans } \\
\cline { 2 - 5 } & MIC $(\mathbf{m g} / \mathbf{m L})$ & $\mathbf{M B C}(\mathbf{m g} / \mathbf{m L})$ & MIC $(\mathbf{m g} / \mathbf{m L})$ & MBC $(\mathbf{m g} / \mathbf{m L})$ \\
\hline SEO & 3.2 & 3.2 & 6.4 & 12.8 \\
$\alpha$-Pinene & 0.8 & 1.6 & 3.2 & 3.2 \\
$\alpha$-Terpineol & 3.2 & 3.2 & 6.4 & 6.4 \\
Terpinolene & 1.6 & 1.6 & 1.6 & 1.6 \\
Verbenone $^{\text {Miconazole nitrate }}{ }^{\text {a }}$ & 12.8 & 12.8 & 6.4 & 12.8 \\
& $\mathrm{ND}$ & $<0.05$ & $\mathrm{ND}$ & $<0.05$ \\
\hline
\end{tabular}

${ }^{a}$ Miconazole nitrate was used as positive control for inhibiting fungal. ND, not detected.

Previous research proved that essential oil of Euodiae Fructus had antifungal effects against Candida albicans $(\mathrm{MIC}=25.6 \mathrm{mg} / \mathrm{mL}$ ) and essential oil of Rosa had antifungal activities against Candida albicans (MIC $=25 \mathrm{mg} / \mathrm{mL}$ ) [22,23]. Here, SEO had antifungal activities (MIC $=3.2 \mathrm{mg} / \mathrm{mL}$ ). The results of this experiment imply that SEO has better antifungal activities than essential oils of Euodiae Fructus and Rosa. 
Candida albicans is the most common fungus, which found in the gastrointestinal and genitourinary tracts. The mucosa produced by Candida albicans may lead to infections in the gastrointestinal, oral and reproductive tracts when the human immune system was weak. There is currently no effective medicine for rapid clinical cure [24]. SEO and its monomers, such as $\alpha$-pinene, $\alpha$-terpineol and terpinolene, had good antifungal activities against Candida albicans.

\subsection{Antioxidant Activity}

\subsubsection{ABTS Radical Scavenging Activity}

In the early stage, ABTS scavenging rate increased with the increasing concentration of SEO (Figure 1). When the concentrations of SEO were $0.1,0.2,0.4,0.6,0.8$ and $1.0 \mathrm{mg} / \mathrm{mL}$, the ABTS scavenging rates were $37 \%, 54 \%, 75 \%, 84 \%, 90 \%$ and $96 \%$, respectively. The results of ABTS free radical scavenging showed that the free radical scavenging rate of SEO reached $96 \%$ when the concentration of SEO was $1.0 \mathrm{mg} / \mathrm{mL}$, which implied that SEO had great free radical scavenging antioxidant activity.

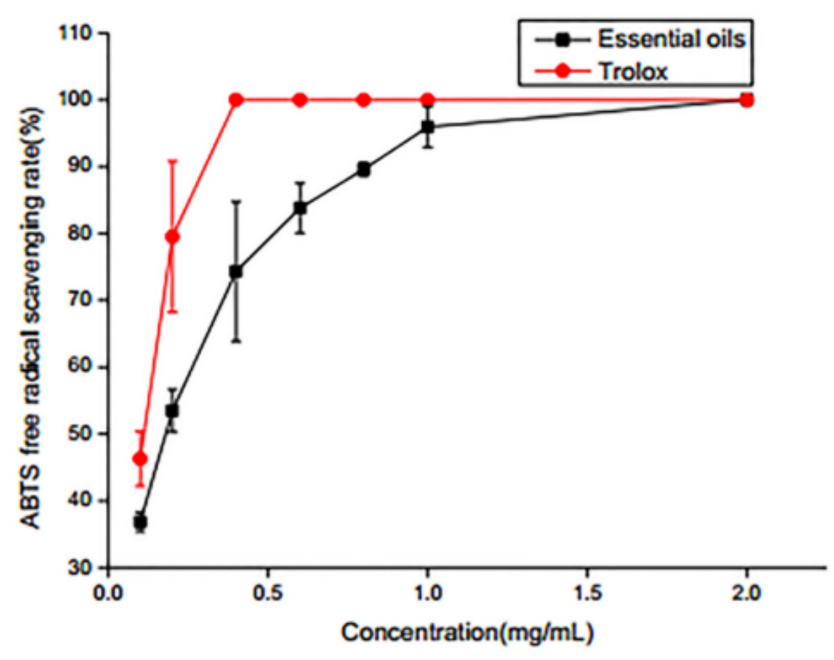

Figure 1. ABTS radical scavenging activity.

\subsubsection{DPPH Radical Scavenging Activity}

$\mathrm{DPPH}$, as a stable free radical, has been widely used as a tool to evaluate free radical scavenging antioxidant activities. As shown in Figure 2, the DPPH free radical scavenging rate depended on the concentration of SEO. DPPH free radical scavenging rates were 15.90\%, 22.40\%, 39.01\%, 65.94\%, 75.25\%, $92.57 \%$ and $100 \%$, when the concentrations of SEO were $1,2,4,6,8,9$ and $10 \mathrm{mg} / \mathrm{mL}$, respectively. It is significant that the DPPH free radical scavenging ability of SEO reached $100 \%$ when the concentration of SEO was $10 \mathrm{mg} / \mathrm{mL}$, which is the same rate as that of the positive control trolox. The DPPH free radical scavenging activity results showed that SEO had good antioxidant activity. The antioxidant properties of terpenes and their derivatives were similar to those of phenolic compounds, which can scavenge free radicals by supplying hydrogen to hydrogen atoms [25]. It has been reported that $\alpha$-pinene and $\alpha$-celene react rapidly with peroxy radicals, resulting in rapid termination of the oxidative chain reaction and thereby reducing the number of reactive free radicals [26].

\subsubsection{Iron Ion Reduction Ability Analysis}

Iron ion reduction ability and the concentration of SEO showed an approximately linear relationship when the concentration of SEO was increased from 0.1 to $8 \mathrm{mg} / \mathrm{mL}$ (Figure 3). The reducing power is related to the absorbance and increases with increasing absorbance. The results show that the iron ion reduction ability of SEO was related to the SEO concentration. The higher concentrations had 
better reducing abilities. When the concentration of SEO reached $8 \mathrm{mg} / \mathrm{mL}$, the reduction ability was the greatest.

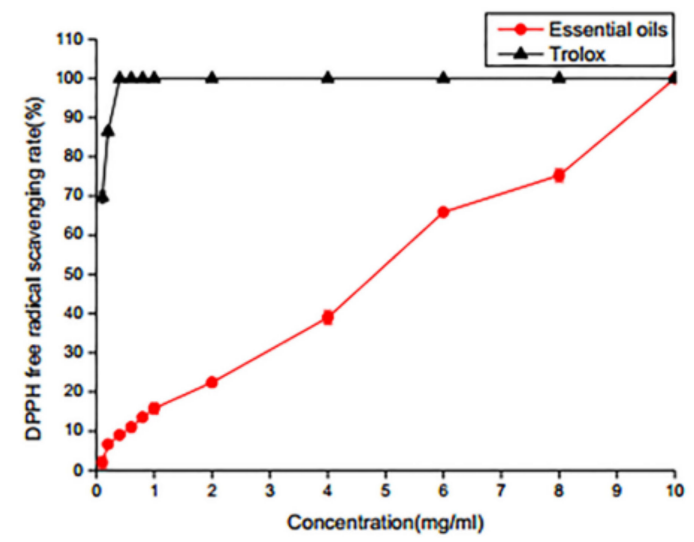

Figure 2. DPPH radical scavenging activity.

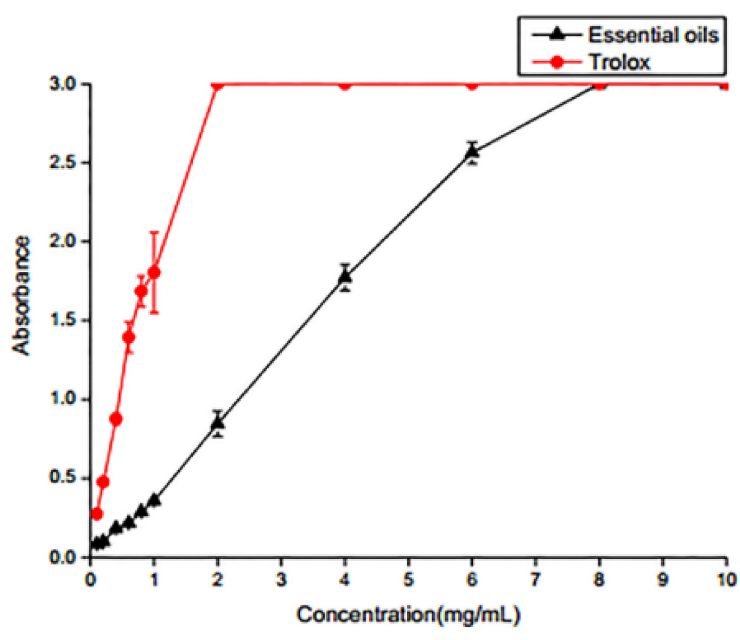

Figure 3. Iron ion reducing ability.

\section{Materials and Methods}

\subsection{Chemical Reagents and Solvents}

Tetracycline hydrochloride, miconazole nitrate, 2,2-diphenyl-1-picrylhydrazyl (DPPH) and ( \pm )-6hydroxy-2,5,7,8-tetramethylchromane-2-carboxylic acid (Trolox) were purchased from Source Leaf Biology Co. (Shanghai, China). Pentadecane, potassium persulfate and 2,2'-azino-bis(3ethylbenzothiazoline-6-sulfonic acid) (ABTS) were purchased from Meilun Biology Co. (Dalian, China). Iron ion reduction capacity kit was purchased from Congyi Biology Co. (Shanghai, China). All other chemical reagents and solvents were of analytical grade. $\alpha$-Pinene (99\%) and $\alpha$-terpineol (97\%) were purchased from Shandong West Asia Chemical Industry Co. (Linyi City, China). Verbenone (97\%) and terpinolene (98\%) were purchased from Beijing Bailingwei Technology Co. (Beijing, China).

\subsection{Plant Materials and Extraction of Essential Oil}

The $4 \mathrm{~kg}$ sunflower receptacles were collected from Da'an City, Jilin Province $\left(123^{\circ} 12^{\prime} 45^{\prime \prime} \mathrm{E}\right.$, $44^{\circ} 52^{\prime} 23^{\prime \prime}$ N) in October 2019 and identified by Professor Shuwen Guan, School of Life Science, Jilin University. The samples were air-dried and then crushed into powder. In each experiment, $100 \mathrm{~g}$ powder was extracted by hydrodistillation in Clevenger-type apparatus for $8 \mathrm{~h}$ [27]. The experiments of 
extraction were repeated 30 times to provide enough SEO for analysis of biological activities. SEO was stored at $4{ }^{\circ} \mathrm{C}$ until analysis.

\subsection{Analysis of Chemical Compositions of Essential Oil}

The sample of SEO $(10 \mu \mathrm{L})$ was diluted in n-hexane $(10 \mu \mathrm{L})$ and analyzed with the Agilent 5975 (Agilent Technologies, Santa Clara, CA, USA). The separation was achieved using an HP-INNOWax capillary column (30 $\mathrm{m} \times 0.25 \mathrm{~mm}$ i.d., $0.25 \mu \mathrm{m}$ film thickness) (Agilent Technologies, Santa Clara, CA, USA). Helium was used as the carrier gas at a flow rate of $1 \mathrm{~mL} / \mathrm{min}$. Injector and detector temperatures were set at 250 and $280{ }^{\circ} \mathrm{C}$, respectively. The oven was maintained at $60{ }^{\circ} \mathrm{C}$ for $3 \mathrm{~min}$ and then programmed to rise to $240{ }^{\circ} \mathrm{C}$ at $5{ }^{\circ} \mathrm{C} / \mathrm{min}$ and held for $15 \mathrm{~min}$ at $240{ }^{\circ} \mathrm{C}$. Electronic ion (EI) mode was set as $70 \mathrm{eV}$, mass spectra were recorded in the 50-550 amu range and the ion source temperature was $230{ }^{\circ} \mathrm{C}$.

Retention indices of the separated compounds on the HP-INNOWax capillary column were determined on the basis of a homologous series of n-alkanes (C9-C30). The compounds of essential oil were identified on the basis of comparison of their retention indices and mass spectra with published data and computer matching with National Institute of Standards and Technology (NIST, 15.0) libraries provided with a computer controlling the GC-MS system. The relative proportions of SEO constituents were expressed as percentages obtained by peak area normalization, and all relative response factors were set as 1 . Pentadecane was used as internal standard and $\alpha$-pinene, verbenone, terpinolene and $\alpha$-terpineol were used as external standards for GC-MS analysis.

\subsection{Antimicrobial Effects}

\subsubsection{Microbial Cultures of Three Bacterial Strains}

Microbial cultures of three bacterial strains (E. coli (ATCC 25922), P. aeruginosa (ATCC 15442) and S. aureus (ATCC 25923)) were purchased from Huan Kai Microbiology Technology Co. (Guangzhou, China). Fungal strains (Candida albicans (ATCC 10231) and S. cerevisiae (ATCC 9080)) were also purchased from Huan Kai Microbiology Technology Co. (Guangzhou, China).

Bacteria strains were resuscitated in lysogeny broth (LB) solid medium. Then, they were transferred to LB liquid medium and incubated at $37^{\circ} \mathrm{C}$ for $24 \mathrm{~h}$. Yeast extract peptone dextrose medium and adenine (YPDA) solid medium was used as a medium for fungal recovery. Then, fungi were transferred to YPDA liquid medium and incubated at $26^{\circ} \mathrm{C}$ for $48 \mathrm{~h}$.

\subsubsection{Detection of Antimicrobial Activities}

The MIC and MBC were measured by using a microplate reader (EL×800, BioTek, Winooski, VT, USA) [15]. Each monomer of essential oil ( $\alpha$-pinene, $\alpha$-terpineol, terpinolene and verbenone) in the culture medium had nine different concentrations, namely 0.05, 0.1, 0.2, 0.4, 0.8, 1.6, 3.2, 6.4 and $12.8 \mathrm{mg} / \mathrm{mL}$. Monomer mixture (with $\alpha$-pinene, $\alpha$-terpineol, terpinolene and verbenone) and SEO in the culture medium had nine different concentrations, namely $0.05,0.1,0.2,0.4,0.8,1.6,3.2,6.4$ and $12.8 \mathrm{mg} / \mathrm{mL}$. A $200 \mu \mathrm{L}$ mixed sample was added to each well of a 96-well microplate. The $200 \mu \mathrm{L}$ mixed sample was mixed with $179 \mu \mathrm{L}$ culture medium, $20 \mu \mathrm{L}$ sample and $1 \mu \mathrm{L} 2.0 \times 10^{6} \mathrm{CFU} / \mathrm{mL}$ bacteria or $2.0 \times 10^{5} \mathrm{CFU} / \mathrm{mL}$ fungi. The bacteria were cultured at $35-37^{\circ} \mathrm{C}$ for $24 \mathrm{~h}$, and the fungi were cultured at $25-26^{\circ} \mathrm{C}$ for $48 \mathrm{~h}$. The absorbance was measured by using the microplate reader at $600 \mathrm{~nm}$. Tetracycline hydrochloride was used as positive control for the antibacterial experiments. Miconazole nitrate was used as positive control for the antifungal experiments. Dimethyl sulfoxide (DMSO) at 5\% $(w / v)$ and DMSO at $1 \%(w / v)$ were used as negative controls of antibacterial and antifungal experiments, respectively. The experiments were carried out in triplicate. 


\subsection{Determination of Antioxidant Activities}

As a single antioxidant method is not able to accurately evaluate the antioxidant activity of SEO, ABTS, DPPH and iron ion reducing ability were used to evaluate the antioxidant activity of SEO.

\subsubsection{ABTS Radical Scavenging}

ABTS radical scavenging activity was determined by the modified protocol from Kang [28]. The ABTS working solution was mixed with 2.6 mmol $\mathrm{K}_{2} \mathrm{~S}_{2} \mathrm{O}_{8}$ and 7.4 mmol ABTS, which was incubated for $12 \mathrm{~h}$ at room temperature in the dark and diluted 40-45 times with ethanol. We added $0.5 \mathrm{~mL}$ sample to $2 \mathrm{~mL}$ ABTS working solution and incubated for $6 \mathrm{~min}$ at room temperature in the dark. The absorbance was measured at $734 \mathrm{~nm}$. Trolox was used as a positive control.

The ABTS scavenging rate was determined by the following formula:

$$
\text { ABTS scavenging rate }=\left[\left(\mathrm{A}_{0}-\mathrm{A}_{1}\right) / \mathrm{A}_{0}\right] \times 100 \%
$$

where $A_{0}$ is the absorbance of the negative control without SEO and $A_{1}$ is the absorbance of the test sample with SEO.

\subsubsection{DPPH Radical Scavenging}

DPPH radical scavenging activity was determined according to the modified protocol from Das [29]. Ethanol and DPPH were mixed to prepare $0.08 \mathrm{mmol} / \mathrm{L}$ DPPH solution, which was stored in the dark. Here, $1 \mathrm{~mL}$ sample and $3 \mathrm{~mL}$ DPPH solution were mixed and kept at room temperature for $30 \mathrm{~min}$ in the dark. The absorption value was measured at $517 \mathrm{~nm}$. Anhydrous ethanol and Trolox were the negative and positive controls, respectively.

The DPPH radical scavenging capacity was determined by the following formula:

$$
\text { DPPH scavenging rate }=\left[\left(\mathrm{A}_{0}-\mathrm{A}_{1}\right) / \mathrm{A}_{0}\right] \times 100 \%
$$

where $A_{0}$ is the absorbance of the negative control without the SEO and $A_{1}$ is the absorbance of the test sample with SEO.

\subsubsection{Iron Ion Reducing Assay}

The iron ion reducing ability was determined using Congyi Biology kit (Shanghai, China), according to the method of Prussian blue [30]. The antioxidant activity can change the ferric iron of potassium ferricyanide to ferrous ions. Which formed to Prussian blue.The material had a maximum absorption peak at $700 \mathrm{~nm}$. A larger absorption value means a better antioxidant capacity of the sample.

\subsection{Statistical Analysis}

All the experiments were conducted with three replications. One-way analysis of variance (ANOVA) and the mean comparisons were performed on all antimicrobial and antioxidant data by using program SPSS 20.0 (IBM Corporation, Armonk, NY, USA). Duncan's multiple range tests were used to calculate the mean values. Differences between mean values at $p<0.05$ were considered significant.

\section{Conclusions}

The work presented in this paper represents the first study on the chemical components and biological activities of SEO. The yield of SEO was $0.42 \%(v / w)$ by hydrodistillation. SEO contained 68 chemical compounds, as determined by GC-MS analysis. The main components were terpenoids, including $\alpha$-pinene and verbenone. Through in vitro antimicrobial experiments, SEO and the monomers ( $\alpha$-pinene, $\alpha$-terpineol, terpinolene and verbenone) were shown to have great antimicrobial effects. The antioxidative abilities (ABTS, DPPH and iron ion reducting ability) were determined in vitro, 
proving that SEO has strong antioxidant effects. Therefore, SEO is worthy of further exploration due to its antibacterial and antioxidant potential.

Author Contributions: L.H., B.G. and W.-N.L. conceived and designed the study. X.-S.L. and Z.-A.Q. performed the experiments. X.-S.L. and L.H. analyzed the data. X.-S.L., L.H. and X.-L.L. wrote the paper. All authors have read and agreed to the published version of the manuscript.

Funding: This research was funded by the National Natural Science Foundation of China (No. 31870201) and research funding from the Key Laboratory for Evolution of Past Life and Environment in Northeast Asia by the Ministry of Education of China. And the APC was funded by the National Natural Science Foundation of China (No. 31870201).

Acknowledgments: We are grateful to Shuwen Guan, School of Life Science, Jilin University, for his helpful plant identification. This work was financially supported by the National Natural Science Foundation of China (No. 31870201) and research funding from the Key Laboratory for Evolution of Past Life and Environment in Northeast Asia by the Ministry of Education of China. We thank Jilin Teyi Food Technology Co., Ltd. For providing research funding and plant materials for this research.

Conflicts of Interest: The authors declare no conflict of interest.

\section{Abbreviations}

$\begin{array}{ll}\text { SEO } & \text { Essential oil from the receptacle of sunflower } \\ \text { GC-MS } & \text { Gas chromatography-mass spectrometry } \\ \text { DPPH } & \text { 2,2-Diphenyl-1-picrylhydrazyl } \\ \text { ABTS } & \text { 2,2-Azino-bis (3-ethylbenzothiazoline-6-sulfonic acid) } \\ \text { MIC } & \text { Minimum inhibitory concentration } \\ \text { MBC } & \text { Minimum bactericidal concentration } \\ \text { P. aeruginosa } & \text { Pseudomonas aeruginosa } \\ \text { S. aureus } & \text { Staphylococcus aureus } \\ \text { S. cerevisiae } & \text { Sacharomyces cerevisiae } \\ \text { E. coli } & \text { Escherichiacoli } \\ \text { RT } & \text { Peak time } \\ \text { RI } & \text { Retention indices } \\ \text { NIST } & \text { National institute of standards and technology } \\ \text { LB } & \text { Lysogeny broth } \\ \text { YPDA } & \text { Yeast extract peptone dextrose medium and adenine } \\ \text { DMSO } & \text { Dimethyl sulfoxide } \\ \text { ANOVA } & \text { One-way analysis of variance }\end{array}$

\section{Appendix A}

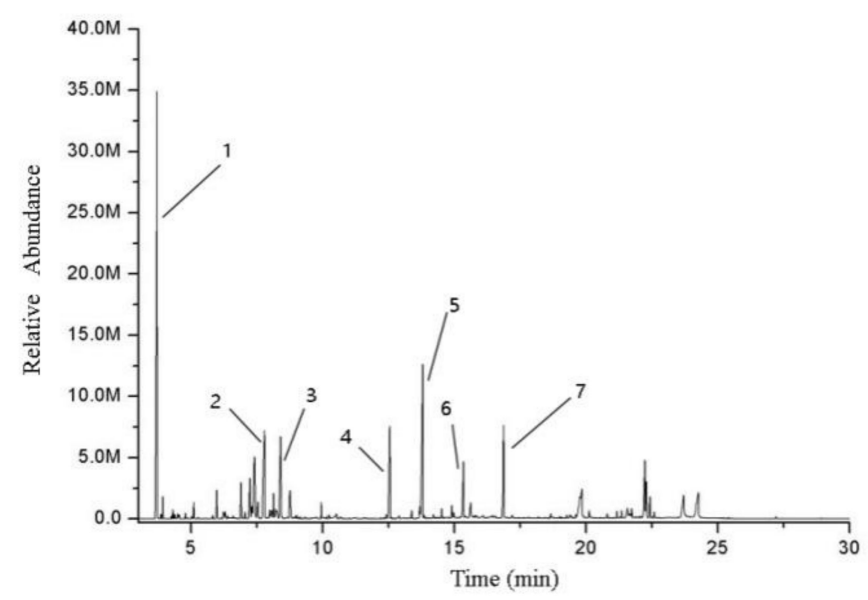

Figure A1. The total ion chromatograms of aroma components of SEOs by GC-MS: (1) $\alpha$-pinene; (2) d-verbenol; (3) verbenol; (4) calarene; (5) pentadecane (internal standard); (6) 3,3,5,6,7-pentamethyl-1-indanone; (7) dehydro-cyclolongifolene oxide. 
Table A1. Quantitative results of some compounds in SEO.

\begin{tabular}{ccc}
\hline & Peak Area & Content (\%) \\
\hline$\alpha$-Pinene & $11,517,282$ & $26.00 \%$ \\
Verbenone & $3,393,766$ & $7.40 \%$ \\
Terpinolene & 562,092 & $1.69 \%$ \\
$\alpha$-Terpineol & 168,387 & $1.27 \%$
\end{tabular}

Peak area: SEO was diluted 5000 times, the corresponding peak area of some compounds ( $\alpha$-pinene, $\alpha$-terpineol, terpinolene, and verbenone). Content (\%): the true content of some compounds ( $\alpha$-pinene, $\alpha$-terpineol, terpinolene, and verbenone) in SEO.

Table A2. Antibacterial activities of SEO and the major monomers

\begin{tabular}{|c|c|c|c|c|c|c|c|c|c|c|c|c|c|c|c|c|c|c|}
\hline & \multicolumn{6}{|c|}{ E. coli } & \multicolumn{6}{|c|}{ P. aeruginosa } & \multicolumn{6}{|c|}{ S. aureus } \\
\hline & MIC & Mean $^{a}$ & SD & MBC & Mean & SD & MIC & Mean & SD & MBC & Mean & SD & MIC & Mean & SD & MBC & Mean & SD \\
\hline Essential oil & 6.4 & 0.15 & 0.126 & 12.8 & 0.06 & 0.016 & 0.2 & 0.03 & 0.005 & 0.2 & 0.03 & 0.005 & 0.2 & 0.161 & 0.007 & 0.4 & 0.045 & 0.01 \\
\hline$\alpha$-Pinene & 12.8 & 0.13 & 0.028 & $>12.8$ & - & - & 6.4 & 0.287 & 0.085 & 12.8 & 0.074 & 0.062 & 6.4 & 0.041 & 0.007 & 6.4 & 0.041 & 0.007 \\
\hline$\alpha$-Terpineol & 6.4 & 0.027 & 0.002 & 6.4 & 0.027 & 0.002 & 3.2 & 0.075 & 0.04 & 6.4 & 0.032 & 0.012 & 6.4 & 0.034 & 0.002 & 6.4 & 0.034 & 0.002 \\
\hline Terpinolene & $>12.8$ & - & - & $>12.8$ & - & - & $>12.8$ & - & - & $>12.8$ & - & - & 6.4 & 0.065 & 0.009 & 6.4 & 0.065 & 0.009 \\
\hline Verbenone & 12.8 & 0.119 & 0.032 & $>12.8$ & - & - & $>12.81 .6$ & - & - & $>12.8$ & - & - & 3.2 & 0.08 & 0.013 & 3.2 & 0.08 & 0.013 \\
\hline Mixture $^{\mathrm{b}}$ & 1.6 & 0.069 & 0.009 & 3.2 & 0.069 & 0.009 & - & 0.034 & 0.001 & 1.6 & 0.034 & 0.001 & 1.6 & 0.039 & 0.008 & 1.6 & 0.039 & 0.008 \\
\hline Tetracycline $^{c}$ & - & - & - & $<0.05$ & 0.032 & 0.002 & & - & - & $<0.05$ & 0.032 & 0.002 & - & - & - & $<0.05$ & 0.037 & 0.007 \\
\hline
\end{tabular}

${ }^{a}$ Mean value of absorbance. ${ }^{b}$ Mixture consists of $\alpha$-pinene, $\alpha$-terpineol, terpinolene, and verbenone $(\mathrm{m}: \mathrm{m}: \mathrm{m}: \mathrm{m}=1: 1: 1: 1) .{ }^{\mathrm{c}}$ Tetracycline hydrochloride was used as positive control for inhibiting bacteria. -, not tested.

Table A3. Antifungal activities of SEO and the major monomers.

\begin{tabular}{|c|c|c|c|c|c|c|c|c|c|c|c|c|}
\hline & \multicolumn{6}{|c|}{ S. cerevisiae (yeast) } & \multicolumn{6}{|c|}{ Candida albicans } \\
\hline & MIC (mg/mL) & Mean & SD & MBC (mg/mL) & Mean & SD & MIC (mg/mL) & Mean & SD & MBC (mg/mL) & Mean & SD \\
\hline Essential oil & 3.2 & 0.144 & 0.016 & 3.2 & 0.144 & 0.016 & 6.4 & 0.085 & 0.009 & 12.8 & 0.043 & 0.112 \\
\hline$\alpha$-Pinene & 0.8 & 0.082 & 0.076 & 1.6 & 0.043 & 0.003 & 3.2 & 0.053 & 0.01 & 3.2 & 0.053 & 0.01 \\
\hline$\alpha$-Terpineol & 3.2 & 0.043 & 0.009 & 3.2 & 0.043 & 0.009 & 6.4 & 0.037 & 0.001 & 6.4 & 0.037 & 0.001 \\
\hline Terpinolene & 1.6 & 0.037 & 0.005 & 1.6 & 0.037 & 0.005 & 1.6 & 0.036 & 0.005 & 1.6 & 0.036 & 0.005 \\
\hline Verbenone & 12.8 & 0.038 & 0.001 & 12.8 & 0.038 & 0.001 & 6.4 & 0.227 & 0.45 & 12.8 & 0.043 & 0.002 \\
\hline Miconazole nitrate ${ }^{a}$ & - & - & - & $<0.05$ & 0.041 & -0.003 & - & - & - & $<0.05$ & 0.062 & 0.006 \\
\hline
\end{tabular}

${ }^{a}$ Miconazole nitrate was used as positive control for inhibiting fungal. 


\section{References}

1. Smith, B.D. Eastern North America as an independent center of plant domestication. Proc. Natl. Acad. Sci. USA 2006, 103, 12223-12228. [CrossRef]

2. Kamal, J. Quantification of alkaloids, phenols and flavonoids in sunflower (Helianthus annuus L.). Afr. J. Biotechnol. 2011, 10, 3149. [CrossRef]

3. Liang, Q.; Cui, J.; Li, H.; Liu, J.; Zhao, G. Florets of Sunflower (Helianthus annuus L.): Potential New Sources of Dietary Fiber and Phenolic Acids. J. Agric. Food Chem. 2013, 2013, 3435-3442. [CrossRef] [PubMed]

4. Ukiya, M.; Akihisa, T.; Yasukawa, K.; Koike, K.; Takahashi, A.; Suzuki, T.; Kimura, Y. Triterpene Glycosides from the Flower Petals of Sunflower (Helianthus annuus) and Their Anti-inflammatory Activity. J. Nat. Prod. 2007, 70, 4. [CrossRef]

5. Saini, S.; Sharma, S. Antidiabetic effect of Helianthus annuus L., seeds ethanolic extract in streptozotocinnicotinamide induced type 2 diabetes mellitus. Int. J. Pharm. Pharm. Sci. 2013, 5, 382-387.

6. Heo, J.-C.; Woo, S.-U.; Kweon, M.-A.; Park, J.-Y.; Lee, H.K.; Son, M.; Rho, J.-R.; Lee, S.-H. Aqueous extract of the Helianthus annuus seed alleviates asthmatic symptoms in vivo. Int. J. Mol. Med. 2008, 21, 5. [CrossRef]

7. Giada, M.D.L.R.; Mancini-Filho, J. Antioxidant capacity of the striped sunflower (Helianthus annuus L.) seed extracts evaluated by three in vitro methods. Int. J. Food Sci. Nutr. 2009, 60, 395-401. [CrossRef]

8. Rubiolo, P.; Sgorbini, B.; Liberto, E.; Cordero, C.; Bicchi, C. Essential oils and volatiles: Sample preparation and analysis. A review. Flavour Fragr. J. 2010, 25, 282-290. [CrossRef]

9. Ceccarini, L.; Macchia, M.; Flamini, G.; Cioni, P.L.; Caponi, C.; Morelli, I. Essential oil composition of Helianthus annuus L. leaves and heads of two cultivated hybrids "Carlos" and "Florom 350". Ind. Crops Prod. 2004, 19, 13-17. [CrossRef]

10. Bertoli, A.; Fambrini, M.; Doveri, S.; Leonardi, M.; Pugliesi, C.; Pistelli, L. Pollen Aroma Fingerprint of two Sunflower (Helianthus annuus L.) Genotypes Characterized by Different Pollen Colors. Chem. Biodivers. 2011, 8, 1766-1775. [CrossRef] [PubMed]

11. Li, L.; Teng, M.; Liu, Y.; Qu, Y.; Zhang, Y.; Lin, F.; Wang, D. Anti-Gouty Arthritis and Antihyperuricemia Effects of Sunflower (Helianthus annuus) Head Extract in Gouty and Hyperuricemia Animal Models. BioMed Res. Int. 2017, 2017, 1-9. [CrossRef]

12. Marechal, V.; Rigal, L. Characterization of by-products of sunflower culture-Commercial applications for stalks and heads. Ind. Crops Prod. 1999, 1995, 185-200. [CrossRef]

13. Ukiya, M.; Sawada, S.; Kikuchi, T.; Kushi, Y.; Fukatsu, M.; Akihisa, T. Cytotoxic and Apoptosis-Inducing Activities of Steviol and Isosteviol Derivatives against Human Cancer Cell Lines. Chem. Biodivers. 2013, 10, 177-188. [CrossRef]

14. Li, L.; Shi, C.; Yin, Z.; Jia, R.; Peng, L.; Kang, S.; Li, Z. Antibacterial activity of -terpineol may induce morphostructural alterations in Escherichia coli. Braz. J. Microbiol. 2014, 45, 1409-1413. [CrossRef] [PubMed]

15. Verma, S.K.; Goswami, P.; Verma, R.S.; Padalia, R.C.; Chauhan, A.; Singh, V.R.; Darokar, M.P. Chemical composition and antimicrobial activity of bergamot-mint (Mentha citrata Ehrh.) essential oils isolated from the herbage and aqueous distillate using different methods. Ind. Crops Prod. 2016, 91, 152-160. [CrossRef]

16. Ćavar, S.; Maksimović, M.; Vidic, D.; Parić, A. Chemical composition and antioxidant and antimicrobial activity of essential oil of Artemisia annua L. from Bosnia. Ind. Crops Prod. 2012, 37, 479-485. [CrossRef]

17. Xing, C.; Qin, C.; Li, X.; Zhang, F.; Linhardt, R.J.; Sun, P.; Zhang, A. Chemical composition and biological activities of essential oil isolated by HS-SPME and UAHD from fruits of bergamot. LWT 2019, 104, 38-44. [CrossRef]

18. Croxen, M.A.; Law, R.J.; Scholz, R.; Keeney, K.M.; Wlodarska, M.; Finlay, B.B. Recent advances in understanding enteric pathogenic Escherichia coli. Clin. Microbiol. Rev. 2013, 26, 822-880. [CrossRef] [PubMed]

19. Katkowska, M.; Garbacz, K.; Kopala, W.; Schubert, J.; Bania, J. Genetic diversity and antimicrobial resistance of Staphylococcus aureus from recurrent tonsillitis in children. APMIS Acta Pathol. Microbiol. Immunol. Scand. 2020, 128, 211-219. [CrossRef]

20. Winstanley, C.; O’Brien, S.; Brockhurst, M.A. Pseudomonas aeruginosa Evolutionary Adaptation and Diversification in Cystic Fibrosis Chronic Lung Infections. Trends Microbiol. 2016, 24, 327-337. [CrossRef]

21. Matasyoh, J.C.; Kiplimo, J.J.; Karubiu, N.M.; Hailstorks, T.P. Chemical composition and antimicrobial activity of essential oil of Tarchonanthus camphoratus. Food Chem. 2007, 101, 1183-1187. [CrossRef] 
22. Liu, S.-S.; Liu, Z.-X.; Wei, H.; Yin, Y.-Y.; Zhang, Q.-W.; Yan, L.-H.; Wang, Z.-M.; Yang, L.-X. Chemical compositions, yield variations and antimicrobial activities of essential oils from three species of Euodiae Fructus in China. Ind. Crops Prod. 2019, 138, 111481. [CrossRef]

23. Yi, F.; Sun, J.; Bao, X.; Ma, B.; Sun, M. Influence of molecular distillation on antioxidant and antimicrobial activities of rose essential oils. LWT Food Sci. Technol. 2019, 102, 310-316. [CrossRef]

24. Nobile, C.J.; Johnson, A.D. Candida albicans Biofilms and Human Disease. Annu. Rev. Microbiol. 2015, 69, 71-92. [CrossRef]

25. Göze, İ.; Vural, N.; Ercan, N. Characterization of Essential oil and Antioxidant Activities of Some Species of Salvia in Turkey. Nat. Volatiles Essent. Oils 2016, 3, 1-7.

26. Amorati, R.; Foti, M.C.; Valgimigli, L. Antioxidant Activity of Essential Oils. J. Agric. Food Chem. 2013, 2013, 10835-10847. [CrossRef]

27. Geng, H.; Yu, X.; Lu, A.; Cao, H.; Zhou, B.; Zhou, L.; Zhao, Z. Extraction, Chemical Composition, and Antifungal Activity of Essential Oil of Bitter Almond. Int. J. Mol. Sci. 2016, 17, 1421. [CrossRef]

28. Kang, J.-H.; Song, K.B. Characterization of Job's tears (Coix lachryma-jobi L.) starch films incorporated with clove bud essential oil and their antioxidant effects on pork belly during storage. LWT Food Sci. Technol. 2019, 111, 711-718. [CrossRef]

29. Das, S.; Singh, V.K.; Dwivedy, A.K.; Chaudhari, A.K.; Upadhyay, N.; Singh, A.; Deepika; Dubey, N.K. Antimicrobial activity, antiaflatoxigenic potential and in situ efficacy of novel formulation comprising of Apium graveolens essential oil and its major component. Pestic. Biochem. Physiol. 2019, 160, 102-111. [CrossRef]

30. Margraf, T.; Karnopp, A.R.; Rosso, N.D.; Granato, D. Comparison between Folin-Ciocalteu and Prussian Blue Assays to Estimate the Total Phenolic Content of Juices and Teas Using 96-Well Microplates. J. Food Sci. 2015, 80, C2397-C2403. [CrossRef]

Sample Availability: Samples of the compounds are not available from the authors.

Publisher's Note: MDPI stays neutral with regard to jurisdictional claims in published maps and institutional affiliations.

(C) 2020 by the authors. Licensee MDPI, Basel, Switzerland. This article is an open access article distributed under the terms and conditions of the Creative Commons Attribution (CC BY) license (http://creativecommons.org/licenses/by/4.0/). 